International Journal of Current Advanced Research

ISSN: O: 2319-6475, ISSN: P: 2319 - 6505, Impact Factor: SJIF: 5.995

Available Online at www.journalijcar.org

Volume 6; Issue 4; April 2017; Page No. 3248-3250

DOI: http://dx.doi.org/10.24327/ijcar.2017.3250.0236

\title{
KNOWLEDGE AND AWARENESS OF DENTAL IMPLANTS AMONG ADULTS IN URBAN AREAS, CHENNAI
}

\author{
*KirenJ., Dhanraj M and Anand S
}

Saveetha Dental College and Hospitals, 162, Poonamallee High Road, Velappanchavadi Chennai-600077,

Tamil Nadu, India

\begin{tabular}{l}
\hline A R T I C L E I N F O \\
Article History: \\
Received $12^{\text {th }}$ January, 2017 \\
Received in revised form $19^{\text {th }}$ February, 2017 \\
Accepted $22^{\text {nd }}$ March, 2017 \\
Published online $28^{\text {th }}$ April, 2017 \\
\end{tabular}

Key words:

Knowledge, Awareness, Dental implants, Adults

\begin{abstract}
A B S T R A C T
Background: Replacement of missing teeth has become one of the most important needs for patients attending clinics to restore aesthetics and/or function. Many treatment modalities are available for replacing a single missing tooth; removable partial denture, fixed partial denture or dental implant.Aim: The objective of this study is to assess the knowledge and awareness of dental implants among adults in urban areas. Methods and Materials: A descriptive design using survey method was used in this study. The study was conducted among adults living in Chennai urban area.Convenient sampling technique was used to select the participants. The survey was conducted among 68 participants using a questionnaire which consists of demographic data and questionnaire on knowledge and awareness on dental implants. Descriptive statistics was used for data analysis. Results: The results of this study shows that more than half of the participants $37(54.4 \%)$ were aware of different dental implants and $31(45.6 \%)$ were not aware of dental implants.About $40(58.8 \%)$ of them think that the best treatment for replacing missing teeth is dental implants. There were $22(32.4 \%)$ of them who felt that high cost is the factor that prevents them from choosing implants for replacing the missing teeth. Conclusion: More than half of the participants were not having information regarding implants. It shows that there is a need for providing more information to the patients about this treatment modality. So, dental education is necessary for developing positive attitude among population regarding dental implants.
\end{abstract}

Copyright $₫ 2017$ KirenJ., Dhanraj M and Anand S. This is an open access article distributed under the Creative Commons Attribution License, which permits unrestricted use, distribution, and reproduction in any medium, provided the original work is properly cited.

\section{INTRODUCTION}

Replacement of missing teeth using implant supported prosthesis for aesthetic and functional rehabilitation has become an accepted and widely used treatment approach in dentistry. Oral rehabilitation is the discipline within dentistry which deals with diagnosis, treatment planning and restoration of larger tooth defects, congenitally or acquired missing teeth and other oral tissues. Awareness and patient's knowledge is one of the factors affecting the final treatment decision regarding the replacement of a missing tooth. Complete information on implant treatment and alternative therapies must be provided to guide the patient in the choice of the most appropriate option. This problem is more magnified in developing nations where there is lack of education and awareness amongst people about dental implants as a dental treatment modality. ${ }^{[1]}$ The treatment can include restoration of teeth with crowns or replacement of teeth with implants, fixed partial dentures or removable dentures. ${ }^{[2]}$ Around one million dental implants are inserted each year, worldwide. ${ }^{[3]}$

*Corresponding author: KirenJ

Saveetha Dental College and Hospitals, 162, Poonamallee

High Road, Velappanchavadi Chennai-600077,

Tamil Nadu, India
Public awareness, positive attitude and acceptance of dental implants were found to be low in a study conducted in Finland. ${ }^{[4]}$ Also Reports from Saudi Arabia and India found levels of awareness about dental implant were $66.4 \%$ and $38 \%$ respectively. ${ }^{[5,6]}$ The results of a study conducted by ElhadiMohieldinAwooda et al.,on 'Knowledge, Attitude and Acceptance of Dental Implants among Patients Attending Khartoum Dental Teaching Hospital' shows that $68.5 \%$ were aware about dental implant as treatment option regarding replacing missing teeth, Of the total participants; $56.8 \%$ didn't know how dental implant lasts, more than half (53.1\%) did not know the place where the implant inserted. Majority (79.4\%) could accept their dentist advice for replacement of missing teeth by implant, but $29.1 \%$ said expensiveness was main barrier against this option. ${ }^{[7]}$

\section{Objective}

The objective of the study is to assess the knowledge and awareness on dental implants among adults in urban areas.

\section{MATERIALS AND METHODS}

A descriptive design using survey method was used to determine the knowledge and awareness of dental implants 
among adults in urban areas. Convenient sampling technique was used to select the participants. Data was collected using a self-developed questionnaire. The questionnaire consists of demographic profile and questionnaire related to knowledge and awareness of dental implants. Closed ended questionnaire was constructed with a total of 8 items designed to assess the patient's acceptance, awareness and knowledge about dental implants as a treatment modality for replacement of missing teeth. In this survey, a total of 68 subjects participated. Descriptive statistics was used for data analysis. The results were analysed and presented in tables and figures. The study was approved by the Institutional Review Board. Informed consent was obtained from the participants before the data collection.

\section{RESULTS}

Figure 1 shows the results of the age of the participants. A majority of them $55(80.9 \%$ ) were under 30 years old, $10(14.7)$ belonged to $30-50$ years and only $3(4.4 \%)$ were above 50 years. Figure 2 shows that there were $30(44.1 \%)$ males and $38(55.9 \%)$ were females. With regards to the educational status, a majority of them 49(72.4\%) hold bachelor's degree. More than half of the participants $37(54.4 \%)$ were aware of different dental implants and 31 $(45.6 \%)$ were not aware of dental implants.
Table 1 shows the response to the questionnaire on the level and knowledge of awareness of dental implants. To the question on where the dental implants are placed, 36(52.9\%) responded as jaw bone, $8(11.8)$ as the gingiva, $1(1.5 \%)$ as neighbouring teeth and $23(33.8 \%)$ did not know the answer. When asked about the survival rate of dental implants, about more than half of them 37 (54.4\%) of them did not know the answer. About 30 (44.1\%) of the participants responded that implant failure could be due to poor oral hygiene.

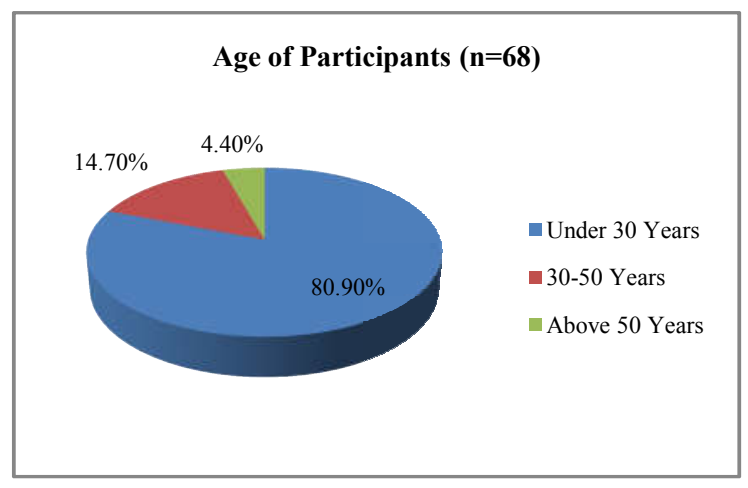

Figure 1 Age of the participants $(\mathrm{n}=68)$

With regards to the care of implants, 32(47.1\%) of them responded that implants needs more care than natural teeth and 15(22.1) did not know the answer.

Table 1 Level of knowledge and awareness of dental implants

\begin{tabular}{|c|c|c|}
\hline Knowledge and Awareness questions & Frequency (n) & Percentage (\%) \\
\hline \multicolumn{3}{|l|}{ 1. Dental implants are placed in } \\
\hline a. the jaw bone & 36 & 52.9 \\
\hline b. the gingiva & 8 & 11.8 \\
\hline c. the neighbouring teeth & 1 & 1.5 \\
\hline d. do not know & 23 & 33.8 \\
\hline \multicolumn{3}{|l|}{ 2. The survival rate of dental implants is } \\
\hline a. less than 5 years & 6 & 8.8 \\
\hline b. $5-10$ years & 13 & 19.1 \\
\hline c. $10-20$ years & 5 & 7.4 \\
\hline d. Up to 20 years & 7 & 10.3 \\
\hline e.do not Know & 37 & 54.4 \\
\hline \multicolumn{3}{|l|}{ 3. Implant failure could be due to } \\
\hline a. poor oral hygiene & 30 & 44.1 \\
\hline b. type of dental implant 6 & 6 & 8.8 \\
\hline c. poor quality of treatment by dentists & 12 & 17.6 \\
\hline d. improper care of implants by self & 13 & 19.15 \\
\hline e. others & 7 & 10.3 \\
\hline \multicolumn{3}{|l|}{ 4. How are the implants cared for ideally? } \\
\hline a. implants should be cleaned like natural teeth & 21 & 30.9 \\
\hline b. Implants needs more care than natural teeth & 32 & 47.1 \\
\hline c. Implants needs less care than natural teeth0 & 0 & 0 \\
\hline d. Do not know & 15 & 22.1 \\
\hline \multicolumn{3}{|l|}{$\begin{array}{l}\text { 5. Which of the following treatment option do you } \\
\text { think is the best treatment for replacing missing teeth? }\end{array}$} \\
\hline a. Dental implants & 40 & 58.8 \\
\hline b. Fixed partial dentures & 14 & 20.6 \\
\hline c. Removable dentures & 10 & 14.7 \\
\hline d. Others & 4 & 5.9 \\
\hline \multicolumn{3}{|l|}{$\begin{array}{l}\text { 6. Which of the following factors prevents you from } \\
\text { choosing implants for replacing the missing teeth? }\end{array}$} \\
\hline a. High cost & 22 & 32.4 \\
\hline b. The need for surgery & 13 & 19.1 \\
\hline c. Long-time treatment & 6 & 8.8 \\
\hline $\begin{array}{l}\text { d. Lack of sufficient knowledge and information about } \\
\text { implants }\end{array}$ & 20 & 29.4 \\
\hline e. Fear & 7 & 10.3 \\
\hline \multicolumn{3}{|l|}{ 7. Implants should only be inserted by specialists } \\
\hline a. Yes & 59 & 86.8 \\
\hline b. No & 3 & 4.4 \\
\hline c. Do not know & 6 & 8.8 \\
\hline
\end{tabular}




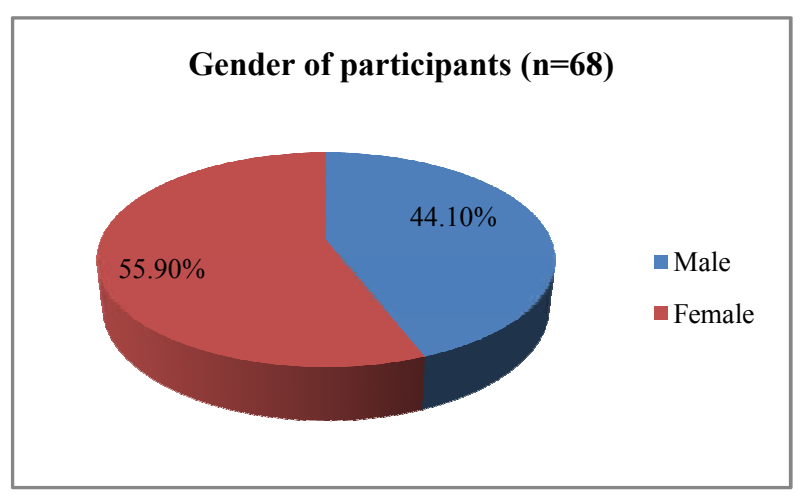

Figure 2 Gender of the participants $(\mathrm{n}=68)$

About $40(58.8 \%)$ of them think that the best treatment for replacing missing teeth is dental implants. There were 22 $(32.4 \%)$ of them who felt that high cost is the factor that prevents them from choosing implants for replacing the missing teeth. Only $7(10.3 \%)$ had fear, which prevented them to choose implants. A majority of them 59(86.8\%) felt that implants should only be inserted by specialist and 6(8.8\%) did not know the answer.

\section{DISCUSSION}

The study results show that almost half of the participants 37 (54.4\%) are aware of different implants. A majority of them $59(86.8 \%)$ are aware that implants should be inserted by specialists. The results of the study conducted in a Turkish sub population in 2014 shows that among the different options to rehabilitate tooth missing, 43.5\% knew about dental implants as a treatment option. ${ }^{[8]}$

The study results are also similar to the study conducted by Saha A et al., on Awareness among patients regarding Implants as a treatment option for replacement of missing teeth in Chattisgarh, which showed around $41.7 \%$ of the subjects were aware of dental implants. High cost of the procedure was the main factor for not undergoing treatment procedure $(35.2 \%)$. Studies conducted by Zimmer et al., Berge and Tepper et al. reported high level of awareness as $77 \%, 70.1 \%$ and $72 \%$, respectively. ${ }^{[9,10,11]}$ Since, in this present study, only $54.4 \%$ of the participants are aware of the implants in this study, dental education can be given to patients to provide sufficient and realistic implant information.

\section{CONCLUSION}

The study shows that the participants have limited awareness about dental implants. Many of them do not have the education or background knowledge on implants. Regardless of whether dentists are dealing with implants or not, it is crucial to know whether today's patients are aware of dental implants as a treatment option and whether the information that they have is realistic.
Awareness amongst patients regarding the dental implants can help in eliminating any negative image of the procedure that may have been caused due to lack of adequate information. As this survey was conducted in a limited group of people, further studies are needed to be conducted amongst a larger group of people.

\section{References}

1. Firas A Al-Quran, Raed F Al-Ghalayini and Bashar N Al-Zu'bi. Single-tooth replacement: factors affecting different prosthetic treatment modalities. BMC Oral Health 2011; 11: 34.

2. Saha A, Dutta S, Vijaya V, Rajnikant N. Awareness among patients regarding Implants as a treatment option for replacement of missing teeth in Chattisgarh. J Int Oral Health 2013; 5:48-52.

3. Pommer B, Zechner W, Watzak G, Ulm C, Watzek G, Tepper G. Progress and trends in patients' mindset on dental implants. I: level of information, sources of information and need for patient information. Clin Oral Implants Res. 2011; 22:223-229.

4. Salonen MA. Assessment of states of dentures and interest in implant-retained prosthetic treatment in 55year-old edentulous Finns. Community DentOralEpidemiol. 1994; 22:130-5.

5. Al-Johany S AZH, Al Juhaini M, Al Refeai M. Dental patients' awareness and knowledge in using dental implants as an option in replacing missing teeth: A survey in Riyadh, Saudi Arabia. Saudi Dent J 2010; 22: $183-8$.

6. Ravi Kumar C, Pratap K. V. N. R, Venkateswararao G. Dental Implants As An Option In Replacing Missing Teeth: A Patient Awareness Survey In Khammam, Andhra Pradesh. Indian Journal of Dental Sciences 2011; 5.

7. ElhadiMohieldin A et al. Knowledge, Attitude and Acceptance of Dental Implants among Patients Attending Khartoum Dental Teaching Hospital. IOSR Journal of Dental and Medical Sciences 2014; 13: 1923.

8. CeydaOzçakır T, ZeynepOzkurt K, Kemal Ş. Patients' knowledge and awareness of dental implants in a Turkish subpopulation. J AdvProsthodont 2014; 6: 133-137.

9. Zimmer CM, Zimmer WM, Williams J, Liesener J. Public awareness and acceptance of dental implants. Int J Oral Maxillofac Implants 1992; 7: 22823.

10. Berge TI. Public awareness, information sources and evaluation of oral implant treatment in Norway. Clin Oral Implants Res 2000; 11: 401-408.

11. Tepper G, Haas R, Mailath G, Teller C, Zechner W, Watzak G, Watzek G. Representative marketingoriented study on implants in the Austrian population. I. Level of information, sources of information and need for patient information. Clin Oral Implants Res $2003 ; 14: 621-633$.

\section{How to cite this article:}

KirenJ et al (2017) ' Knowledge And Awareness Of Dental Implants Among Adults In Urban Areas, Chennai', International Journal of Current Advanced Research, 06(04), pp. 3248-3250.

DOI: http://dx.doi.org/10.24327/ijcar.2017.3250.0236 